\title{
Effects of lipopolysaccharide-induced inflammation on hypoxia and inflammatory gene expression pathways of the rat testis
}

\author{
Michael A. Palladino*, Genevieve A. Fasano, Dharm Patel, Christine Dugan and Marie London
}

\begin{abstract}
Background: Bacterial infection and inflammation of the testis impairs fertility, yet an understanding of inflammatory responses of the testis is incomplete. We are interested in identifying gene pathways involved in the detection and clearance of infectious microbes in the male reproductive tract. In previous studies in our lab focused on hypoxia-responsive genes of the testis, preliminary experiments suggested that genes classically categorized as hypoxia genes are also activated during antimicrobial responses. The purpose of this study was to identify hypoxia and inflammatory gene pathways that contribute to antimicrobial protection of the testis and to consider possible cross-talk and interactions between these pathways. Inflammation was induced in Sprague-Dawley rats using P. aeruginosa or E. coli lipopolysaccharide (LPS). Levels of hypoxia-inducible factor-1 (HIF-1a) protein and nuclear factor kappa B (NF-KB) were measured, and hypoxia and inflammatory gene expression patterns in testis were analyzed by gene expression profiling using real-time quantitative PCR arrays.

Results: In LPS-treated rats, HIF-1a protein increased with no change in Hif-1a mRNA. Western Blot analysis also demonstrated no change in NF-KB and inhibitory NFKB alpha (IKBa) protein levels following LPS treatment. Five hypoxia pathway genes (Angpt14, Egr1, ler3, Pail, and Glut1), and 11 inflammatory pathway genes (Ccl12, Cc13, Cd14, Cxcl10, Icam1, I110, I116, Il6, Nfkbia, T/r2, Tnf) up-regulated after $3 \mathrm{~h}$ of inflammation. Angpt/4, Ccl12, Cc13, Cd14, Egr1, Nfkbia, TIr2, and Thf remained elevated at 6 h. Six genes were up-regulated at 6 h only (Bhlhe40, C3, Jak2, NIrp3, Slc1 Ial, T/r1). One gene (T/r5) was down-regulated after $3 \mathrm{~h}$ and no genes at $6 \mathrm{~h}$. Electrophoretic mobility shift assay results suggest a decrease in NF-KB binding activity following LPS treatment.

Conclusions: Testicular HIF-1a is up-regulated following LPS-induced inflammation. In contrast to other tissues, in which HIF-1a is up-regulated through transcriptional activation via NF-KB, we conclude that HIF-1a in the testis is not up-regulated through an increase in Hif-1a mRNA or through NF-kB-dependent mechanisms. Hypoxia pathway genes and genes involved in Toll-like receptor (TLR) and cytokine-mediated signaling comprise major functional categories of up-regulated genes, demonstrating that both hypoxia and classic inflammatory pathways are involved in inflammatory responses of the testis.
\end{abstract}

Keywords: Hypoxia, Orchitis, Pathogens, Lipopolysaccharide, Inflammation

\footnotetext{
* Correspondence: mpalladi@monmouth.edu

Note: Co-authors GF, DP, CD and ML were students at Monmouth University

when the work was carried out. All have graduated and are currently in

graduate school, medical school or in positions in industry

Monmouth University, 400 Cedar Avenue, West Long Branch, NJ 07764, USA
}

(c) The Author(s). 2018 Open Access This article is distributed under the terms of the Creative Commons Attribution 4.0 International License (http://creativecommons.org/licenses/by/4.0/), which permits unrestricted use, distribution, and reproduction in any medium, provided you give appropriate credit to the original author(s) and the source, provide a link to the Creative Commons license, and indicate if changes were made. The Creative Commons Public Domain Dedication waiver (http://creativecommons.org/publicdomain/zero/1.0/) applies to the data made available in this article, unless otherwise stated. 


\section{Résumé}

Contexte: L'infection et l'inflammation bactériennes du testicule altèrent la fertilité; cependant la compréhension des réponses inflammatoires du testicule est. encore incomplète. Nous nous sommes intéressés à l'identification des voies des gènes impliqués dans la détection et l'élimination des microbes infectieux dans l'appareil reproductif masculin. Dans de précédentes études menées dans notre laboratoire, et centrées sur des gènes sensibles à I'hypoxie, les expérimentations préliminaires suggéraient que les gènes classiquement catégorisés comme gènes de I'hypoxie étaient aussi activés au cours des réponses antimicrobiennes. Le but de la présente étude était d'identifier les voies des gènes qui contribuaient à la protection antimicrobienne du testicule et d'examiner de potentiels intermodulations et interactions entre ces voies.

L'inflammation a été induite chez des rats Sprague-Dawley en utilisant des lypopolysaccharides (LPS) de $P$. aeruginosaet d'E. coli. Les taux de protéine du facteur-1 inductible par l'hypoxie (HIF1- a) et du facteur nucléaire kappa B (NF- ${ }_{k} B$ ) ont été mesurés; les profils d'expression des gènes de l'hypoxie et de l'inflammation dans le testicule ont été analysés par profilage de l'expression génique par PCR quantitative en temps réel.

Résultats: Chez les rats traités par LPS, la protéine HIF-1 a a augmenté sans modification de Hif-1amRNA. L'analyse par Western Blot a aussi montré l'absence de modifications des taux de NF-kB et de la protéine inhibitrice NFKB alpha $\left(l_{k} B\right.$ a) après traitement. Cinq gènes de la voie hypoxie (Angpt/4, Egr1, ler3, Pai1,et Glut1), et 11 gènes de la voie inflammatoire (CCl12, CC13, Cd14, Cxcl10, Icam1, I110, II16, II6, Egr1, Nfkbia, T/r2, et Tnf) ont été régulés à la hausse après 3 heures d'inflammation. Angpt/4, Ccl12, Cc13, Cd14, Egr1, Nfkbia, T/r2, et Tnfsont restés élevés à 6 heures. Six gènes n'ont ont été régulés à la hausse qu'à 6 heures (Bhlhe40, C3, Jak2, N/rp3, Slc11a1, T/r1). Un gène (T/r5) a été régulé à la baisse après 3 heures et aucun gène à 6 heures. Les résultats du test de décalage de la mobilité électrophorétique suggèrent une baisse de l'activité de liaison de NF- ${ }_{k} B$ après traitement par LPS.

Conclusions: HIF-1a testiculaire est. régulé à la hausse après inflammation induite par LPS. Contrairement à d'autres tissus, dans lesquels HIF-1a est. régulé à la hausse par activation transcriptionnelle via NF- ${ }_{k} B$, nous concluons que HIF-1 a dans le testicule n'est. pas régulé à la hausse par une augmentation de Hif-1 amRNA ou par des mécanismes NF-k-dépendants. Les gènes de la voie hypoxie et les gènes impliqués dans le récepteur Toll-like (TLR) et dans la signalisation médiée par les cytokines comprennent des catégories fonctionnelles majeures de gènes régulés à la hausse, ce qui démontre qu'à la fois les voies de l'hypoxie et les voies classiques de l'inflammation sont impliquées dans les réponses inflammatoires du testicule.

Mots-clés: Hypoxie, Orchite, Pathogènes, Lypopolysaccharides, Inflammation

\section{Background}

Infection and resulting inflammation of male reproductive organs impairs fertility by decreasing sperm mobility through the tract and reducing androgen production among other effects on spermatozoa and on the testis and epididymis [1-3]. Roughly half of all infertility cases are caused by male infertility and over $30 \%$ of male infertility is idiopathic, yet the relevance of infection and inflammation in male infertility, although widely studied clinically, is still subject to debate $[4,5]$. Research to better understand the effects of pathogens on the male reproductive tract and cellular and molecular mechanisms involved in the detection and response to infection of male reproductive organs is essential.

In vivo and in vitro models involving the administration of lipopolysaccharide (LPS), a major pathogenic component of the cell wall of Gram negative bacteria, is a common experimental approach to evaluate inflammatory responses [6, 7]. Pathogen-specific recognition sensors, such as Toll-like receptors (TLR), have been identified in the testis and implicated in the physiology of Leydig, Sertoli and spermatogenic cells $[8,9]$. It is well-known that across species a number of antimicrobial peptides are produced by the testis including Spag11, members of the defensin family, Eppin and others $[8,10-17]$.

Effects of uropathogenic bacteria and LPS in the testis include inhibition of steroidogenesis and reduced androgen production $[18,19]$, decreased intracellular cAMP and reduced sperm motility [20], induction of proinflammatory cytokines and activation of antimicrobial pathways [10], and epigenetic regulation of antimicrobial gene expression [21]. However, relatively little is known about interactions between regulatory pathways and mechanisms involved in the response to inflammation of the testis.

In other tissues, cross-talk between hypoxia regulatory pathways and classic inflammatory pathways has been demonstrated [22, 23]. This led us to hypothesize that both pathways contribute significantly to inflammatory responses of the testis. We were intrigued by this hypothesis in part because of our prior work on testis 
hypoxia and the transcription factor hypoxia-inducible factor-1 (HIF-1). Recognized as the master regulator of hypoxia, HIF-1 is known to activate transcription of over 100 genes crucial for cellular responses to hypoxia [2426]. Increasingly, HIF-1 activation has been implicated in a range of inflammatory responses [27]. For example, HIF-1 is induced by proinflammatory cytokines such as tumor necrosis factor alpha (TNF- $\alpha)$ and interleukin beta (IL-1ß) [28], and by LPS under normoxic conditions [29].

HIF- $1 \alpha$ is expressed by Leydig cells in the normoxic adult rat testis and is unregulated by hypoxia [30]. We have also demonstrated that myeloid leukemia cell differentiation 1 $(\mathrm{Mcl}-1)$ is a target gene for testicular HIF-1 with potentially important roles in antiapoptotic protection of Leydig cells [31]. Understanding mechanisms of HIF-1 activation under normoxic, hypoxic, and other physiological conditions, such as inflammation, in the testis is of significant interest to investigators interested in the roles of HIF-1 on Leydig cell physiology.

The present study was initiated to (1) investigate whether HIF-1 is affected by LPS-induced inflammation of the testis as an initial step to determine if co-activation of hypoxia and inflammatory pathways occurs in the testis, (2) determine if other hypoxia pathway genes are activated by inflammation, and (3) to explore potential cross-talk between expression of hypoxia and inflammatory pathway genes.

\section{Methods}

\section{Animals}

Adult male, retired-breeder Sprague-Dawley rats (475750 g, 9-12 months, Charles River Laboratories (Stone Ridge, NY) were housed individually on a 12:12-h light/ dark cycle and controlled temperature with free access to food and water.

\section{Administration of Lipopolysaccharides}

P. aeruginosa LPS (Type 10, L7018; Sigma-Aldrich, St. Louis, Missouri) and E. coli 055:B5 LPS (L2880; Sigma-Aldrich) were selected because both are from known pathogens of the urogenital tract and cause tissue-specific inflammatory responses. A dosage of $5.0 \mathrm{mg} / \mathrm{kg}$ body weight was chosen to maximize activation of inflammatory responses. Others have clearly demonstrated LPS doses that generate inflammatory responses in vivo (1-5 $\mathrm{mg} / \mathrm{kg}$ body weight) and in vitro $(0.1-1.0 \mathrm{mg} / \mathrm{ml})$, models $[10,16,18,19,32]$. LPS was reconstituted in sterile $1 \times$ phosphate buffered saline (PBS; $10 \mathrm{mM}$ sodium phosphate, $150 \mathrm{mM}$ sodium chloride, $\mathrm{pH}$ 7.8) and administered via intraperitoneal injection. Sham controls were injected with sterile PBS. After $1,3,6$, and $12 \mathrm{~h}$ of treatment ( $n=5-7 /$ time point), animals were euthanized via $\mathrm{CO}_{2}$ gas. Testes and control tissues were excised then frozen in liquid nitrogen and stored at $-80{ }^{\circ} \mathrm{C}$.

\section{Serum testosterone assays}

Blood was collected via cardiac puncture at the time of sacrifice, clotted at room temperature for $30 \mathrm{~min}$, centrifuged at $13,000 \mathrm{rpm}$ for $10 \mathrm{~min}$ at $4{ }^{\circ} \mathrm{C}$ then sera was removed and stored at $-80{ }^{\circ} \mathrm{C}$ prior to testosterone measurements. Testosterone radioimmunoassays were carried out using a Packard 1900TR Liquid Scintillation Analyzer (Canberra, Meriden, CT). Internal controls included a no testosterone control and a positive control sample of $100 \mathrm{ng} / \mathrm{ml}$ testosterone.

\section{Protein extraction}

Frozen tissue samples were homogenized on ice in three volumes of lysis buffer (10 mM Tris-HCL [pH 7.5], $1.5 \mathrm{mM} \mathrm{MgCl}, 1 \mathrm{mM}$ dithiothreitol, $1 \mathrm{mM} \mathrm{Na} \mathrm{VO}_{4}$ containing protease inhibitor cocktail; P8340; Sigma-Aldrich). The homogenate was maintained on ice for $10 \mathrm{~min}$ then centrifuged for $5 \mathrm{~min}$ at $3500 \mathrm{rpm}$ at $4{ }^{\circ} \mathrm{C}$. Supernatant was removed for cytoplasmic proteins. $\mathrm{Nu}-$ clei were resuspended in three volumes of $0.42 \mathrm{M} \mathrm{KCl}$, $20 \mathrm{mM}$ Tris-HCL (pH 7.5), $1.5 \mathrm{mM} \mathrm{MgCl}_{2}, 20 \%$ glycerol, mixed for $30 \mathrm{~min}$ at $150 \mathrm{rpm}$ at $4{ }^{\circ} \mathrm{C}$, and centrifuged at $13,500 \mathrm{rpm}$ for $30 \mathrm{~min}$ at $4{ }^{\circ} \mathrm{C}$ to isolate nuclear proteins. Protein extracts were stored at $-80{ }^{\circ} \mathrm{C}$ and protein concentrations determined by the Bradford assay (Bio-Rad, Hercules, CA).

\section{Immunoblot analysis}

Proteins were separated by denaturing sodium dodecyl sulfate polyacrylamide gel electrophoresis (SDS-PAGE) through 7.5\% PAGEr ${ }^{\circ}$ Gold Precast Gels (Lonza, Rockland, MD) in $1 \times$ Tris-glycine SDS buffer $(0.25 \mathrm{mM}$ Tris, $192 \mathrm{mM}$ glycine, and 0.1\% ( $w / v)$ SDS [pH 8.3]). COS-7 simian virus 40-transformed kidney cell nuclear extract (Active Motif, Carlsbad, CA) was included as a positive control for detecting HIF-1 $\alpha$. RAW 264.7 cell extract (Santa Cruz Biotechnology, Santa Cruz, CA) was in-

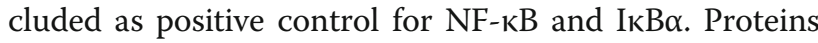
were electroblotted onto Trans-Blot nitrocellulose (Bio-Rad), blocked with $1 \times$ Western wash $(50 \mathrm{mM}$ Tris, $30 \mathrm{mM} \mathrm{NaCl}, 0.001 \%$ Tween 20 [pH 7.6]) containing 5\% nonfat dry milk (NFDM) for $30 \mathrm{~min}$ at room temperature, then incubated in primary antibody overnight at $4{ }^{\circ} \mathrm{C}$ in $1 \times$ Western wash, 5\% NFDM.

Primary antibody dilutions were as follows: $0.5 \mu \mathrm{g} / \mathrm{mL}$ HIF- $1 \alpha$ mouse monoclonal antibody (AF1935; R\&D Systems, Minneapolis, MN), $0.5 \mu \mathrm{g} / \mathrm{mL}$ NF- $\mathrm{kB}$ rabbit polyclonal antibody (ADI-KAP-TF112, Enzo Life Sciences, Farmingdale, NY), $0.5 \mu \mathrm{g} / \mathrm{mL}$ IKB rabbit polyclonal antibody (9242; Cell Signaling, Danvers, MA). Actin was detected as a loading control for protein quantification using 
a 1:2000 dilution of rabbit polyclonal antibody (A2066, Sigma-Aldrich). Blots were incubated in $1 \times$ Western wash, 5\% NFDM containing appropriate horseradish peroxidase (HRP)-conjugated secondary antibodies (1:20,000 dilution), washed in $1 \times$ Western wash, developed by enhanced chemiluminescence using either SuperSignal ${ }^{\circ}$ West Pico substrate or SuperSignal ${ }^{\circ}$ West Femto substrate (Pierce, Rockford, IL), and analyzed with a ChemiDoc ${ }^{\mathrm{Tm}} \mathrm{XRS}+\mathrm{Mo}-$ lecular Imager with Image Lab ${ }^{\text {Tw }}$ Software (Bio-Rad).

\section{Gene expression profile analysis by real-time quantitative PCR (qPCR)}

Total RNA was isolated from frozen tissue using TRIzol reagent (Invitrogen, Grand Island, NY). Gene expression profiles for hypoxia pathway genes and inflammatory pathway genes were analyzed using Rat Hypoxia Signaling Pathway and Rat Innate and Adaptive Immune Response Pathway $\mathrm{RT}^{2}$ Profiler $^{\mathrm{Tm}}$ PCR Arrays (Qiagen, Frederick, $\mathrm{MD})$. One microgram of genomic-DNA-free total RNA was reverse transcribed using the $\mathrm{RT}^{2}$ First Strand cDNA Kit (330,401, Qiagen). Real-time qPCR assays were carried out with SYBR Green dye and amplified for 40 cycles in a Stratagene Mx3500P $\mathrm{P}^{\circ}$ thermocycler. Each array contained 84 genes involved in the hypoxia or innate and adaptive immune response pathways. Listings of all genes queried and accession numbers are available from the Qiagen website.

Positive controls and housekeeping genes were included to normalize for differences in sample loading, genomic DNA contamination, and amplification efficiency. PCR controls included no RT and no template negative controls. Relative quantification of all target genes was calculated by first normalizing comparative cycle threshold $\left(C_{t}\right)$ values of target genes to $B$-actin. Normalized values were used to calculate target gene expression in treatment groups compared to shams. $\mathrm{C}_{\mathrm{t}}$ values of controls were $\sim 8-10$ cycles beyond RT test samples indicating that no contaminating DNA was present. Genes that displayed an average $(n=4-7)$ minimum of three-fold change (up- or down-regulation) were considered statistically significant $(p<0.05)$ by analysis of variance (ANOVA).

\section{In silico analysis}

Computer-based (in silico) methods were utilized for the analysis of candidate genes involved in inflammatory responses of the testis. Methods included literature searches using PubMed (http://www.ncbi.nlm.nih.gov/ pubmed/) and bioinformatics databases such as UniProt (https://www.uniprot.org) for gene expression and protein distribution data. These electronic resources were used to determine if there was existing data available about these genes, such as expression and regulation data, cell-type-specific expression in the testis, and

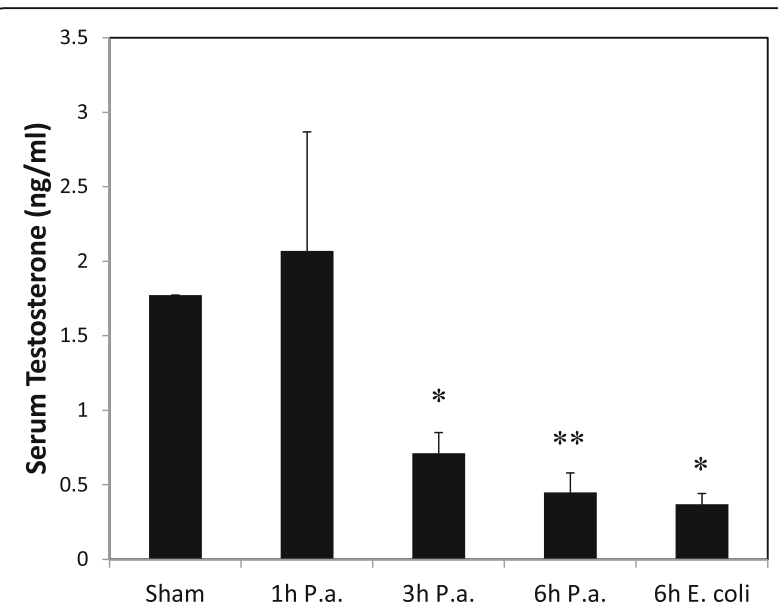

Fig. 1 Serum testosterone levels decrease following LPS-induced inflammation. *Indicates statistically significant difference as compared to sham (ANOVA, $P<0.05 ; n=3-5$ ); ${ }^{* *}$ Indicates $P<0.001$. P.a., Pseudomonas aeruginosa

protein expression data from other researchers. Information about each gene of interest was gathered to propose pathway maps. The Database for Annotation, Visualization, and Integrated Discovery (DAVID) Bioinformatics Resources 6.7 available through the $\mathrm{Na}$ tional Institute of Allergy and Infectious Diseases (NIAID) was utilized for functional annotation and pathway map analysis (https://david.ncifcrf.gov).

\section{Electrophoretic mobility shift assays}

Electrophoretic Mobility Shift Assays (EMSA) were performed using the Thermo Scientific LightShift ${ }^{\circ}$ Chemiluminescent EMSA kit according to manufacturer's instructions (Thermo Scientific, Rockford, IL). Terminal deoxynucleotidyl transferase (TdT) was used to catalyze biotin labeling of oligonucleotides (Biotin 3' End DNA Labeling Kit, Pierce). Binding reactions were carried out in $20 \mu \mathrm{l}$ volumes with protein extracts incubated with $10 \times$ binding buffer, $1 \mu \mathrm{g} / \mu \mathrm{l}$ poly $(\mathrm{dI} \bullet \mathrm{dC}), 50 \%$ glycerol, $1 \%$ $\mathrm{NP}-40,1 \mathrm{M} \mathrm{KCl}, 100 \mathrm{mM} \mathrm{MgCl}$, and $200 \mathrm{mM}$ EDTA and biotin-labeled oligonucleotide for $20 \mathrm{~min}$ at room temperature. Epstein-Barr Nuclear Antigen (EBNA) and biotin-labeled double-stranded target DNA were included as positive controls. Unlabeled EBNA oligonucleotides were used in negative control and competition experiments. NF- $\kappa B$ double-stranded oligonucleotide with a consensus binding site for NF- $\mathrm{kB} / \mathrm{c}$-Rel homodimeric and heterodimeric complexes (5'-AGTTGAGGGGACTTTCC CAGGC -3'; sc-2505, Santa Cruz Biotechnology) which is similar to the sequence present in the upstream region of the HIF-1 gene and mutant oligonucleotides (sc-2511) with a C-G substitution in the consensus site were used for EMSA. 


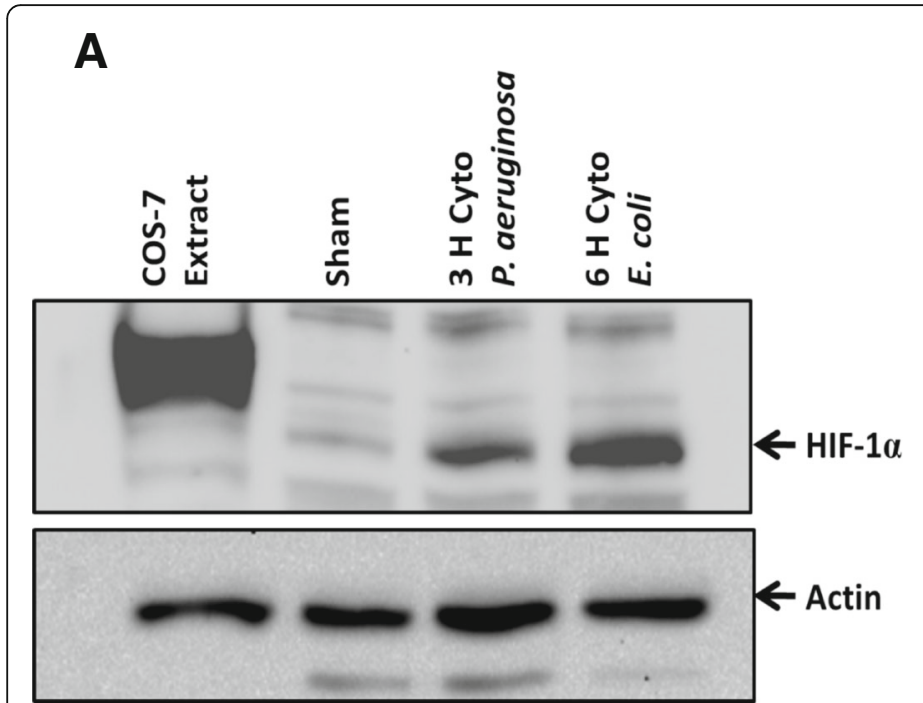

B

Fig. 2 HIF-1a protein levels increase following LPS-induced inflammation in rat testis. a Results of HIF-1a immunoblot analysis of testicular cytoplasmic proteins isolated from sham and LPS treated animals. COS-7 cell line protein extract was included as a positive control and B-actin was included as an internal control. HIF-1a was detected at $\sim 120 \mathrm{kDa}$. Shown is a $6 \mathrm{~h}$ sham as an example but time-matched shams (1, 3 and $6 \mathrm{~h}$ ) were used for all experiments and for quantitation. Representative time points and results are shown in panel (a). b Histogram shows relative HIF-1a protein levels normalized to B-actin and as compared to sham for all time points and treatment samples analyzed. *Indicates statistically significant difference as compared to sham (ANOVA, $P<0.05 ; n=4-7$ ). ${ }^{* *}$ Indicates $P<0.001$

EMSA reactions were separated through $6 \%$ polyacrylamide TBE PAGEr ${ }^{\circ}$ Gold gels (Lonza) electrophoresed in $0.5 \times$ tris-borate-EDTA buffer (AccuGENE ${ }^{\bullet} 10 \times$ TBE Buffer, $^{2}$ Lonza), transferred onto nylon (Biodyne ${ }^{\circ} \mathrm{B}$, Thermo Scientific) and membranes cross-linked at $120 \mathrm{~mJ} / \mathrm{cm}^{2}$ for $60 \mathrm{~s}$ using a UV-light cross-linker. Blots were blocked, incubated with a 1:300 dilution of stabilized streptavidin-HRP conjugate for $15 \mathrm{~min}$ at room temperature, then reacted with luminal/enhancer solution. Digital images were captured with a ChemiDoc ${ }^{\mathrm{Tw}} \mathrm{XRS}+$ quantitative analysis performed using Image Lab ${ }^{\text {tw }}$ Software.

\section{Results}

\section{Serum testosterone levels decrease following LPS} treatment

A rat model of orchitis, or testicular inflammation, was established via administration of $P$. aeruginosa or $E$. coli LPS at a dosage of $5 \mathrm{mg} / \mathrm{kg}$ bw. It is well-established that one effect of LPS on the testis is diminished testosterone output and reductions in plasma testosterone levels [19]. To determine if $1 \mathrm{~h}, 3 \mathrm{~h}$, and $6 \mathrm{~h} \mathrm{P}$. aeruginosa and $6 \mathrm{~h}$ E. coli LPS treatment caused acute inflammation of the testis and the expected reduction in circulating testosterone, serum testosterone levels were measured via radioimmunoassay. No decrease in serum testosterone levels was observed at $1 \mathrm{~h} \mathrm{P}$. aeruginosa LPS treatment (Fig. 1). Statistically significant decreases in serum testosterone levels were observed at $3 \mathrm{~h}$ and $6 \mathrm{~h} P$. aeruginosa and $6 \mathrm{~h} E$. coli LPS treatment as compared to sham $(P<0.05$; Fig. 1), demonstrating the expected and well-reported physiological effect of LPS inflammation on the testis under our experimental conditions.

Increased expression of $\mathrm{Il}-6$ has been reported in the testis following LPS-induced inflammation at both 3 and 9-h time points [21]. As mentioned later in the manuscript, we detected elevated mRNA expression for Il-6 mRNA in $3 \mathrm{~h}$ LPS treatment groups providing further evidence for inflammation of the testis under these experimental conditions (see Table 2).

\section{HIF-1a protein levels increase following LPS-induced inflammation}

To determine if testis inflammation results in the activation of hypoxia pathways through HIF-1, HIF-1 $\alpha$ protein levels in testis from sham and treatment groups were detected by Western blot analysis (Fig. 2a). Statistically significant increases in HIF- $1 \alpha$ protein were observed at $1 \mathrm{~h}$, $3 \mathrm{~h}$ and $6 \mathrm{~h} \mathrm{P}$. aeruginosa LPS treatment as compared to sham and following $6 \mathrm{~h} \mathrm{E}$. coli LPS treatment (Fig. 2b). In an initial pilot study to determine time course and LPS dosage, $1 \mathrm{~h}$ and $3 \mathrm{~h} \mathrm{E}$. coli LPS treatment experiment was performed but no apparent changes in HIF- $1 \alpha$ protein were detected (data not shown), therefore it appears that $P$. aeruginosa LPS produces a more acute phase response in elevating HIF-1 than E. coli LPS.

\section{NF-KB and IKB protein levels following LPS-induced inflammation}

NF- $\mathrm{kB}$ is a major activator of inflammatory pathways and has been shown to transcriptionally regulate HIF-1 under 

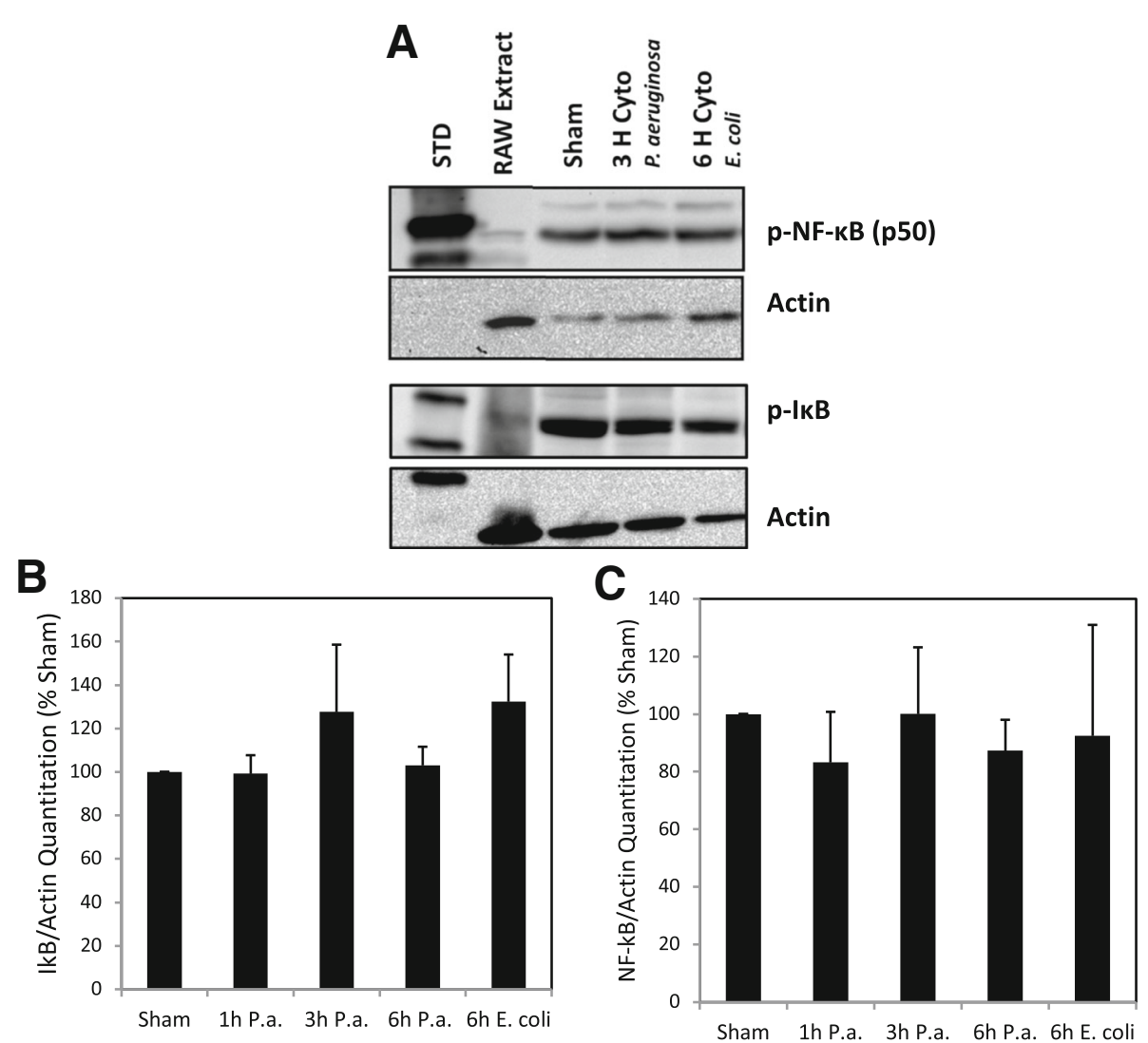

Fig. 3 Phospho-NF-KB and IKB protein levels do not change following LPS-induced inflammation in rat testis. a Results of phospho-NF-KB and phospho-IKB immunoblot analysis of testicular cytoplasmic proteins isolated from sham and LPS treated animals. RAW cell line protein extract was included as a positive control and B-actin was included as an internal control. Representative time points and results are shown in panel (a). Histograms show relative phospho-IKB (b) and phospho-NF-KB (c) protein levels normalized to B-actin and as compared to sham for all time points and treatment samples analyzed. No statistically significant differences in phospho-IKB and phospho-NF-KB protein levels were observed between sham and LPS treated groups (ANOVA, $P<0.05 ; n=3-5$ ). STD, protein molecular weight standards

conditions of inflammation in other cell types [33, 34]. In an effort to identify the mechanism(s) responsible for HIF- $1 \alpha$ protein accumulation following LPS-induced inflammation of the testis, phospho-NF- $\mathrm{KB}$ and phospho-IкB protein levels in testicular cytoplasmic protein extracts were measured via Western blot analysis. No differences in phospho-NF- $\mathrm{kB}$ and phospho-IкB protein levels were observed in the testis following LPS-induced inflammation at all time points as compared to sham $(P<0.05$; Figs. 3a-c).

\section{NF-KB DNA binding activity decreases following LPS- induced inflammation}

EMSAs were performed to evaluate the DNA binding activity of NF- $\mathrm{KB}$. An oligonucleotide with a consensus binding site for NF- $\mathrm{kB}$ homo- and heterodimeric complexes, similar in sequence to a binding site upstream of the HIF-1 gene, was used for EMSA with both testicular cytoplasmic and nuclear protein extracts (Fig. 4a). These time points were chosen to determine if there was any difference in inflammatory response caused by the different treatments. A decrease in binding activity was observed in the cytoplasmic extracts of both $3 \mathrm{~h} \mathrm{P}$. aeruginosa and $6 \mathrm{~h}$ E. coli LPS treatment and nuclear extracts of $6 \mathrm{~h}$ E. coli LPS treatment as compared to sham $(P<0.05$; Fig. 4b).

\section{Gene expression profiling of hypoxia pathway genes}

That HIF-1 increased following LPS-induced inflammation suggests roles for hypoxia regulated genes in inflammatory responses of the testis. Gene expression profiling arrays were used to identify hypoxia pathway genes that are regulated following LPS administration. Also, to determine if regulation of HIF- $1 \alpha$ protein accumulation following LPS-induced inflammation of the testis occurs at the transcriptional level, Hif- $1 \alpha$ mRNA levels were measured in these arrays. No statistical significant difference in Hif- $1 \alpha$ mRNA levels was observed at any time point following LPS-induced inflammation in the testis by the arrays or by independent RT-PCR assays for Hif- $1 \alpha$ (data not shown), suggesting that HIF-1 protein up-regulation is occurring at the post-transcriptional level. Stabilization and degradation 


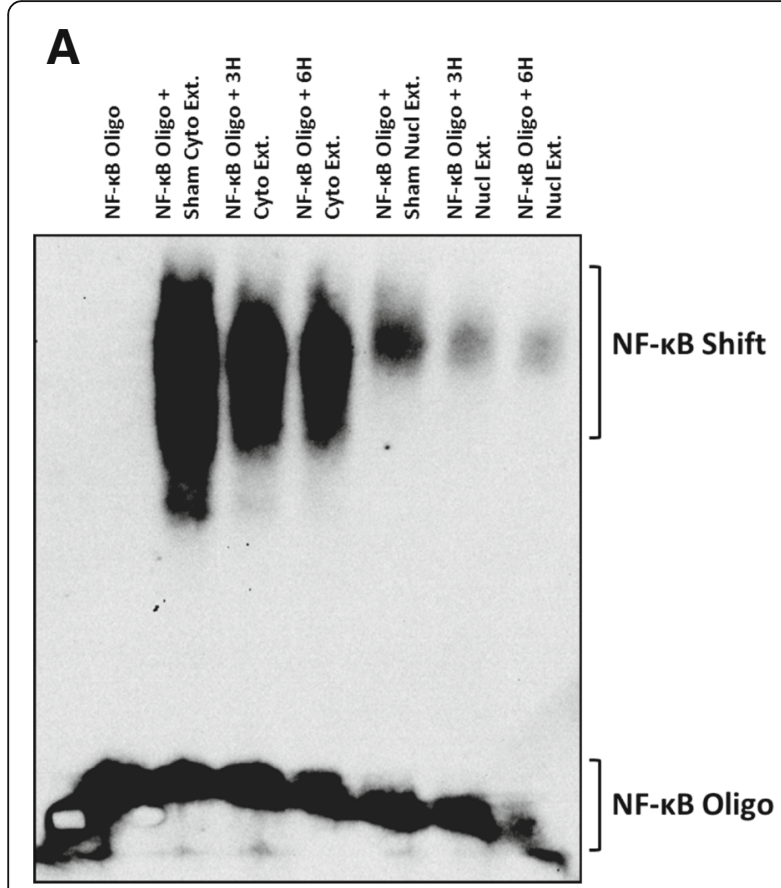

B

Fig. 4 Electrophoretic mobility shift assay (EMSA) for NF-KB binding to the HIF-1a gene. a NF-KB binding to a consensus sequence from the HIF-1a gene in both cytoplasmic and nuclear protein extracts decreased following LPS treatment. b Relative DNA binding activity as compared to sham. ${ }^{*}$ Indicates statistically significant difference as compared to sham (ANOVA, $n=3-5 ; P<0.05$ ). ${ }^{* *}$ Indicates $P<0.001$

of HIF-1 protein is very well characterized as the primary mechanism controlling HIF-1 protein levels [26].

Pathway array results demonstrated that 5 genes in the hypoxia pathway, Angptl4, Egr1, Ier3, Pai1, and Slc2a1 (Glut1), were up-regulated after $3 \mathrm{~h}$ of LPS-induced inflammation and expression and showed more than a three-fold change $(p<0.05$; Table 1$)$. Following $6 \mathrm{~h}$ of LPS-induced inflammation, 3 of these genes (Angptl4, Bhlhe40, and Egr1), showed statistically significant up-regulation (Table 1). No genes were down-regulated following LPS administration. In silico analysis of
LPS-stimulated genes indicates that these transcripts are predominantly expressed in supporting cells of the testis (Sertoli, myoid, and Leydig cells) and not in developing germ cells. Egr1, Fos, Ier3, and Pai1 are known target genes for the transcription factor NF-kB. None of the up-regulated genes are known HIF-1 targets.

\section{Gene expression profiling of innate and adaptive immune response pathway genes}

Because recent research has demonstrated cross-talk between hypoxia pathways and inflammatory pathways, we

Table 1 Up-regulation of hypoxia pathway genes after 3 and 6 h of LPS-induced inflammation

\begin{tabular}{lll}
\hline Gene Name Unigene, GenBank & Fold Change & $6 h(n=6)$ \\
\cline { 2 - 3 } & $3 h(n=7)$ & $14.12(p=0.005)$ \\
Angiopoietin-like 4 (Angpt/4)Rn.119611, NM_199115 & $20.38(p=0.007)$ & 3.31 \\
Basic helix-loop-helix family, member (Bh/he40) & No change & $(p=0.000)$ \\
Rn.81055, NM_053328 & & 6.67 \\
Early growth response 1 (Egr1) & 29.16 & $(p=0.046)$ \\
Rn.9096, NM_012551 & $(p=0.006)$ & No change \\
Immediate early response 3 (ler3) & 9.85 & No change \\
Rn.23638, NM_212505 & $(p=0.001)$ & \\
Plasminogen activator inhibitor type 1 (Pai1) & 15.05 & No change \\
Rn.29367, NM_012620 & $(p=0.023)$ & 3.41 \\
Solute carrier family 2 (facilitated glucose transporter), & $(p=0.002)$ & \\
member 1 (Slc2a1, Glut1) & &
\end{tabular}


chose to also evaluate expression profiles for innate and adaptive immune response genes. At $3 \mathrm{~h}$ following $P$. aeruginosa LPS treatment, 11 genes showed a statistically significant up-regulation $(C c 112, C c 13, C d 14$, Cxc110, Icam1, Il10, Il1b, Il6, Nfkbia, Tlr2, and Tnf) and one gene was down-regulated (Tlr5; Table 2). Twelve genes were up-regulated at $6 \mathrm{~h}(C 3, C c 112, C c 13, C d 14$, Il1b, Jak2, Nfkbia, Nlrp3, Slc11a1, Tlr1, Tlr2, and Tnf). Seven genes remained elevated at both 3 and $6 \mathrm{~h}$ (Cc112, Cc13, Cd14, Il1b, Nfkbia, Tlr2, and Tnf).

\section{Pathway analysis of inflammatory genes affected by LPS-induced inflammation}

DAVID Bioinformatics Resources 6.7 was utilized for functional annotation and pathway map analysis. This allowed for identification of multiple genes involved in specific signaling pathways. Of the inflammatory genes affected by LPS, 9 genes are part of the TLR signaling pathway (Additional file 1: Figure S1). With the exception of Tlr5, which was down-regulated $3 \mathrm{~h}$ following LPS-induced inflammation, genes circled in red were

Table 2 Changes in expression of genes involved in innate and adaptive immune responses after 3 and 6 h of LPS-induced inflammation

\begin{tabular}{|c|c|c|c|}
\hline \multirow[t]{2}{*}{ Gene Name } & \multicolumn{2}{|c|}{ Fold Change } & \multirow[t]{2}{*}{ Gene Functions } \\
\hline & $3 \mathrm{~h}$ & $6 \mathrm{~h}$ & \\
\hline $\begin{array}{l}\text { Complement component } 3 \text { (C3) } \\
\text { Rn.11378, NM_016994 }\end{array}$ & No change & $\begin{array}{l}7.72 \\
(p=0.002)\end{array}$ & Activation of the complement system. \\
\hline $\begin{array}{l}\text { Chemokine (C-C motif) ligand } 12 \\
\text { (CC112); Rn.137780, NM_001105822 }\end{array}$ & $\begin{array}{l}8.52 \\
(p=0.000)\end{array}$ & $\begin{array}{l}26.15 \\
(p=0.035)\end{array}$ & $\begin{array}{l}\text { Angiogenesis; cellular response to fibroblast growth } \\
\text { factor stimulus; participates in chemokine and cytokine } \\
\text { mediated and cytokine signaling pathways. }\end{array}$ \\
\hline $\begin{array}{l}\text { Chemokine (C-C motif) ligand } 3 \text { (Cc13) } \\
\text { Rn.10139, NM_013025 }\end{array}$ & $\begin{array}{l}10.62 \\
(p=0.000)\end{array}$ & $\begin{array}{l}14.63 \\
(p=0.043)\end{array}$ & Monokine with inflammatory and chemokinetic properties. \\
\hline $\begin{array}{l}\text { CD } 14 \text { molecule (Cd14) } \\
\text { Rn.42942, NM_021744 }\end{array}$ & $\begin{array}{l}7.17 \\
(p=0.002)\end{array}$ & $\begin{array}{l}6.67 \\
(p=0.002)\end{array}$ & Accessory protein for TLR4. \\
\hline $\begin{array}{l}\text { Chemokine (C-X-C motif) ligand } 10 \\
\text { (CXC110); Rn.10584, NM_139089 }\end{array}$ & $\begin{array}{l}24.23 \\
(p=0.000)\end{array}$ & NSS & $\begin{array}{l}\text { Proinflammatory cytokine; may participate in T-cell effector } \\
\text { function and development. Inhibits expression of StAR D1. }\end{array}$ \\
\hline $\begin{array}{l}\text { Intercellular adhesion molecule } 1 \\
\text { (1 cam1) Rn. 12, NM_012967 }\end{array}$ & $\begin{array}{l}25.26 \\
(p=0.000)\end{array}$ & NSS & $\begin{array}{l}\text { Up-regulated by TLR2, TLR4, TLR5, and TLR6; ligand for } \\
\text { leukocyte adhesion protein. }\end{array}$ \\
\hline $\begin{array}{l}\text { Interleukin } 10 \text { (1110) } \\
\text { Rn.9868, NM_012854 }\end{array}$ & $\begin{array}{l}4.43 \\
(p=0.021)\end{array}$ & No change & Inhibits cytokine synthesis. \\
\hline $\begin{array}{l}\text { Interleukin } 1 \text { beta (111b) } \\
\text { Rn.9869, NM_031512 }\end{array}$ & $\begin{array}{l}11.32 \\
(p=0.000)\end{array}$ & $\begin{array}{l}14.18 \\
(p=0.053)\end{array}$ & Endogenous pyrogen, proinflammatory cytokine. \\
\hline $\begin{array}{l}\text { Interleukin } 6 \text { (116) } \\
\text { Rn.9873, NM_012589 }\end{array}$ & $\begin{array}{l}69.61 \\
(p=0.000)\end{array}$ & NSS & $\begin{array}{l}\text { Disrupts integrity of blood-testis-barrier by altering steady } \\
\text { state levels of membrane proteins. }\end{array}$ \\
\hline $\begin{array}{l}\text { Janus kinase } 2 \text { (Jak2) } \\
\text { Rn.18909, NM_031514 }\end{array}$ & No change & $\begin{array}{l}3.77 \\
(p=0.032)\end{array}$ & $\begin{array}{l}\text { Non-receptor tyrosine kinase known to be involved in innate } \\
\text { and adaptive immunity signaling. }\end{array}$ \\
\hline $\begin{array}{l}\text { Nuclear factor of kappa light polypeptide } \\
\text { gene (Nfkbia) } \\
\text { Rn.12550, NM_001105720 }\end{array}$ & $\begin{array}{l}4.84 \\
(p=0.000)\end{array}$ & $\begin{array}{l}3.99 \\
(p=0.018)\end{array}$ & Inhibitor of NF-kB; binds NF-kB and retains it in the cytoplasm. \\
\hline $\begin{array}{l}\text { NLF family, pyrin domain containing } \\
3 \text { (NIrp3) } \\
\text { Rn.214177, XM_220513 }\end{array}$ & No change & $\begin{array}{l}8.27 \\
(p=0.001)\end{array}$ & No functional assignments in Uniprot. \\
\hline $\begin{array}{l}\text { Solute carrier family } 11 \text { (proton-coupled } \\
\text { divalent; SIc1 1a1) } \\
\text { Rn.105919, NM_001031658 }\end{array}$ & No change & $\begin{array}{l}3.79 \\
(p=0.000)\end{array}$ & $\begin{array}{l}\text { Macrophage protein associated with resistance or susceptibility } \\
\text { to intracellular pathogens. }\end{array}$ \\
\hline $\begin{array}{l}\text { Toll-like receptor } 1 \text { (T/r1) } \\
\text { Rn. 107,212, NM_001172120 }\end{array}$ & No change & $\begin{array}{l}3.36 \\
(p=0.018)\end{array}$ & Stimulated by bacterial lipoproteins. \\
\hline $\begin{array}{l}\text { Toll-like receptor } 2 \text { (T/r2) } \\
\text { Rn. 46,387, NM_198769 }\end{array}$ & $\begin{array}{l}6.35 \\
(p=0.000)\end{array}$ & $\begin{array}{l}8.70 \\
(p=0.027)\end{array}$ & $\begin{array}{l}\text { Increase expression of inflammatory cytokines IL-a, IL-6, and } \\
\text { interferon- } a \text {, and } \beta\end{array}$ \\
\hline $\begin{array}{l}\text { Toll-like receptor } 5 \text { (T/r5) } \\
\text { Rn. 198,962, NM_001145828 }\end{array}$ & $\begin{array}{l}-3.37 \\
(p=0.052)\end{array}$ & No change & $\begin{array}{l}\text { Increase expression of inflammatory cytokines IL-a, IL- } 6 \text {, and } \\
\text { interferon- } a \text {, and } \beta\end{array}$ \\
\hline $\begin{array}{l}\text { Tumor necrosis factor (TNF superfamily, } \\
\text { member 2; Tnf) } \\
\text { Rn.2275,NM_012675 }\end{array}$ & $\begin{array}{l}8.78 \\
(p=0.000)\end{array}$ & $\begin{array}{l}4.58 \\
(p=0.029)\end{array}$ & $\begin{array}{l}\text { Chemokine-mediated signaling, induces germ cell apoptosis in } \\
\text { autoimmune orchitis. }\end{array}$ \\
\hline
\end{tabular}


up-regulated at 3 and/or $6 \mathrm{~h}$ following LPS administration (Additional file 1: Figure S1).

\section{Discussion}

This study was designed to begin to understand effects of $E$. coli and $P$. aeruginosa LPS-induced inflammation in activating HIF-1 and hypoxia pathway gene responses in the testis. Regulation of HIF-1 during inflammation has been studied in vivo and in vitro and reviewed extensively [23]. One hypothesis is that HIF-1 is up-regulated in microenvironments of inflamed tissues characterized by low levels of oxygen and glucose and high levels of inflammatory cytokines, reactive oxygen species (ROS), and nitrogen species, to protect cells against secondary inflammatory damage [32].

Steroidogenesis and spermatogenesis are inhibited by infection and inflammation of the testis [18]. For example, in mice using relatively high doses of LPS, Leydig cell steroidogenesis is inhibited via reduced synthesis of the cholesterol transport protein steroidogenic acute regulatory protein and steroidogenic enzymes [19]. To validate inflammation in our model system, serum testosterone levels were measured and decreases in serum testosterone after the $3 \mathrm{~h}$ and $6 \mathrm{~h} \mathrm{P}$. aeruginosa and $6 \mathrm{~h}$ $E$. coli LPS treatments confirmed LPS-induced inflammation and compromised testicular functions.

Previously we have shown that HIF-1 is highly expressed by normoxic Leydig cells and that, unlike other tissues, testicular HIF-1 expression is not induced by hypoxia [35]. This may be because physiologic oxygen tension of the testis is already hypoxic. Thus, studying the activation of a hypoxic response during inflammation in what may be an already hypoxic environment is of particular interest. In vitro studies have established the activation of hypoxia genes by LPS in multiple systems including pulmonary artery smooth muscle cells, macrophages, monocytes, and glioblastomas [33, 34, 3638]. The increase in testicular HIF-1 protein we detected following LPS-induced inflammation indicates a role for HIF-1 and Leydig cells in the activation of (or protection against) an inflammatory response.

The accumulation of testicular HIF- $1 \alpha$ protein following inflammation suggests crosstalk between inflammatory responses and hypoxic responses in the testis. Before determining the effects of HIF-1 up-regulation following LPS-induced inflammation, we chose to make an initial effort to identify potential pathways responsible for the crosstalk between inflammatory and hypoxic responses and up-regulation of HIF-1 $\alpha$. Studies suggest this crosstalk occurs via transcriptional regulation of HIF- $1 \alpha$ by NF- $\kappa B$, a key transcription factor responsible for mediating inflammatory responses [34, 37]. A functional NF- $\mathrm{kB}$ binding site in the HIF- $1 \alpha$ promoter has been demonstrated [36] and LPS induces HIF-1 activation in human monocytes via NF- $\mathrm{BB}$ [33].

This led us to consider that NF- $\mathrm{kB}$ may be an important transcriptional activator of HIF- $1 \alpha$ following LPS-induced inflammation in our model. EMSA experiments to measure NF- $\mathrm{KB}$ binding to the HIF-1 $\alpha$ promoter revealed that binding activity decreased following LPS-induced inflammation. $N f k b 1$ mRNA and protein expression did not increase and our pathway array results also demonstrated increased expression of Nfkbia mRNA. Taken together these results suggest that NF- $\mathrm{kB}$ is probably not a transcriptional activator of HIF- $1 \alpha$ in the testis in vivo.

We also demonstrated that testicular HIF- $1 \alpha$ is not up-regulated through an increase in Hif- $1 \alpha$ mRNA. It is likely then that post-translational regulation of HIF-1 $\alpha$ protein levels (via ubiquitination and protein stability) as occurs under hypoxic conditions, and not transcriptional regulation of HIF- $1 \alpha$ is the likely mechanism for up-regulating HIF- $1 \alpha$ protein levels in the testis during inflammation.

One of the functional clusters of inflammatory genes up-regulated in our study is the TLRs. In our work expression of Tlr2 was shown to be elevated at both 3 and 6-h time points but Tlr4 mRNA was not. Although others have demonstrated elevated expression of TLR-4 following LPS challenge of the testis [10]. But the absence of significant change in expression of Tlr4 has been reported before. For example, Winnall et al. reported a significantly higher expression of TLR2 in relation to expression of the LPS receptor TLR4 and its co-receptor protein CD14 [7]. Sertoli cells have been shown to respond to bacteria through both TLR2 and TLR4 [39]. TLR4-dependent activation of HIF-1 in the lung has been demonstrated [40]. Our studies showed elevated expression of CD14. In addition, TLR stimulation elevates the synthesis of proinflammatory cytokines such as IL-1 $\beta$ and TNF (both of which showed elevated mRNA expression in our study) so perhaps TLR-dependent pathways and not NF- $\mathrm{kB}$ is the predominant activation pathway for HIF-1 in the testis. Recently we have also demonstrated that expression of a number of microRNAs in the testis are downregulated by LPS including miRNAs involved in regulating the NF- $\mathrm{kB}$ pathway [41].

Testicular macrophages are important for modulating inflammatory responses [1]. In testicular macrophages challenged with LPS, it has been shown that the NF- $\mathrm{kB}$ signaling pathway is blocked due to a lack of IкB $\alpha$ ubiquitination and degradation [42]. Rather LPS stimulates testicular macrophages to activate MAPK, AP-1, CREB and other pathways that increase production of proinflammatory cytokines such as IL-6 and TNF. Both IL-6 and TNF are known to have inhibitory roles on steroidogenesis of Leydig cells $[1,43]$ and so the elevated mRNA expression of these genes observed in our studies was 
expected. In this study up-regulated expression of mRNAs for proinflammatory cytokines such as IL-1 and IL-6, TNF underscores the importance of cytokine-mediated signaling pathways that are thought to be important for inflammatory responses of the testis, as demonstrated by other investigators [1].

Finally, the up-regulation of HIF-1 $\alpha$ protein may also be caused by several physiologic changes. For example, a decrease in oxygen tension caused by inflammatory activity occurring in the testis may result in a hypoxic environment leading to HIF-1 activation. Similarly ROS released during inflammatory responses can also stabilize and elevate HIF-1 $\alpha$ protein levels [23].

Results from hypoxia pathway arrays demonstrated that six hypoxic pathway genes (Angptl4, Bhlhe40, Egr1, Ier3, Pai1, and Glut1) are up-regulated 3 or 6 h following LPS-induced inflammation. Among 84 hypoxic genes, no genes appear to be down-regulated in response to LPS. Those that did show a significant increase do not appear to belong to any particular functional cluster. Due to the variety of functions exhibited by these genes, we do not want to speculate about the roles these genes may plan in inflammatory responses in the testis. These genes are the subject of future studies.

Although we did not determine the cell-type specific location of the genes analyzed in our study, in silico analysis of hypoxia pathways genes revealed that only Bhlhe 40 is known to be expressed in spermatogenic cells. Angptl4, Egr1, Ier3, and Pai1 are expressed in myoid cells. Pai1 is expressed in germ cells. Egr1, Ier3, Pail, and Slc2a1 are expressed in Sertoli cells, and Egr1 is expressed in Leydig cells. These results suggest that supporting cells, and not germ cells, are primarily involved in inflammatory responses of the testis.

In addition, the literature includes few studies on hypoxic gene expression in the testis in response to LPS. Bourdon et al. detected Pail expression in cultured Sertoli cells following LPS treatment [44]. Further experimental evidence is necessary to elucidate the specific mechanisms and functions of these genes, and will provide a greater understanding of why some appear to be early response genes while others may be late responders. These studies could also provide an explanation for why certain genes such as Angptl4 and Egr1 show a sustained response, with elevated expression at both 3 and 6-h time points.

While the up-regulation of HIF-1 $\alpha$ suggests a role for the HIF-1 pathway in inflammatory responses of the testis, further studies are needed to determine possible HIF-1 target genes. HIF-1 was initially thought to play a significant role in the regulation of these hypoxic genes, but only Glut1 is a known target gene for HIF-1. However, Egr1, Ier3, and Pai1 are known target genes of NF-k $\beta$. Also, although HIF-1 is known to activate over 100 target genes, not all targets were built into the array; therefore, we cannot exclude the possibility that there may be other HIF-1 target genes involved in inflammation.

\section{Conclusions}

Regardless of the underlying reasons for HIF-1 activation, we conclude that the mechanism of HIF- $1 \alpha$ protein accumulation following LPS-induced inflammation is not at the transcriptional level and likely not mediated through NF- $\kappa B$. Further studies will be carried out to identify target genes regulated by HIF-1. This study provides a baseline analysis of hypoxia and inflammatory pathway gene expression changes following LPS-induced inflammation of the testis that will be a useful resource for researchers in the future. The range of genes affected and their potential functions, reflects the complexity of the inflammatory response of the testis and underscores that both hypoxic and inflammatory gene expression pathways are involved.

\section{Additional file}

Additional file 1: Figure S1. Toll-like receptor signaling pathway including innate and adaptive immune response genes up-regulated or downregulated by LPS-induced inflammation. (DOCX 359 kb)

\section{Abbreviations}

ANOVA: analysis of variance; CAMP: cyclic AMP; cDNA: complementary DNA; $C_{t}$ : cycle threshold; DAVID: Database for Annotation, Visualization, and Integrated Discovery; DNA: deoxyribonucleic acid; EBNA: Epstein-Barr Nuclear Antigen; EBNA: Epstein-Barr Nuclear Antigen; EDTA: ethylene-Diamine-TetraAcetic acid; EMSA: Electrophoretic Mobility Shift Assays; HIF-1a: hypoxiainducible factor-1 alpha; HRP: horseradish peroxidase; IL-1ß: interleukin beta; IKBa: inhibitory NFKB alpha; LPS: lipopolysaccharide; Mcl-1: myeloid leukemia cell differentiation 1; NFDM: nonfat dry milk; NIAID: National Institute of Allergy and Infectious Diseases; PBS: phosphate buffered saline; PCR: polymerase chain reaction; $\mathrm{PPCR}$ : real-Time Quantitative PCR; RNA: ribonucleic acid; ROS: reactive oxygen species; RT: reverse transcriptase; SDS-PAGE: sodium dodecyl sulfate polyacrylamide gel electrophoresis; TdT: terminal deoxynucleotidyl transferase; TLR: Toll-like receptor; TNFa: tumor necrosis factor alpha

\section{Acknowledgements}

We thank Dr. Renshan Ge and Chantal Sottas at the Population Council of the Center for Biomedical Research for performing serum testosterone radioimmunoassays. Results from this study were presented at the 34th annual meeting of the American Society for Reproductive Immunology (Long Beach, NY, June 2014), the 39th annual meeting of the American Society of Andrology (Atlanta, GA, April 2014), the 112th Annual Meeting of the American Society for Microbiology (San Francisco, CA, June 2012) and the 37th Annual Meeting of the American Society of Andrology (Tucson, AZ, April 2012).

\section{Funding}

Supported by NIH grant R15-HD046451 to M. Palladino, the Independent College Fund of New Jersey-Merck Undergraduate Science Endeavors Program to support G. Fasano, and the Bristol-Myers Squibb Charitable Giving Grant to the Monmouth University Summer Research Program to support D. Patel. 


\section{Availability of data and materials}

All data generated or analyzed during this study are included in this published article [and its Additional files].

\section{Authors' contributions}

MAP designed the study, participated in its experimental design, data analysis, and drafting and final writing and submission of the manuscript. GAF carried out hypoxia and inflammatory pathway array experiments and drafting of the manuscript. DP carried out western blot experiments and drafting of the manuscript. CD and ML carried out EMSA experiments and drafting of the manuscript. All authors read and approved the final manuscript.

\section{Ethics approval and consent to participate}

Animal research protocols were approved by the Monmouth University IACUC and conform to guidelines established in The Guide for the Care and Use of Laboratory Animals.

\section{Consent for publication}

Not applicable.

\section{Competing interests}

The authors declare that they have no competing interests.

\section{Publisher's Note}

Springer Nature remains neutral with regard to jurisdictional claims in published maps and institutional affiliations.

Received: 30 July 2018 Accepted: 15 October 2018

Published online: 16 November 2018

\section{References}

1. Hedger MP. The Immunophysiology of male reproduction. Knobil and Neill's physiology of reproduction. 4th ed. London: Academic Press; 2015.

2. Azenabor A, Ekun $A O$, Akinloye O. Impact of inflammation on male reproductive tract. J Reprod Infertil. 2015;16:123-9.

3. Bachir BG, Jarvi K. Infectious, inflammatory, and immunologic conditions resulting in male infertility. Urol Clin North Am. 2014:41:67-81.

4. Ochsendorf FR. What are the consequences of sexually transmitted infections on male reproduction? Handbook of Andrology. Lawrence: Allen Press, Inc; 2009.

5. Hamada A, Esteves SC, Agrawal A. The role of contemporary andrology in unraveling the mystery of unexplained male infertility. Open Reprod Sci J. 2011;3:27-41.

6. Hedger M, Klug J, Fröhlich S, Müller R, Meinhardt A. Regulatory cytokine expression and interstitial fluid formation in the normal and inflamed rat testis are under leydig cell control. J Androl. 2005;26:379-86.

7. Winnall WR, Muir JA, Hedger MP. Differential responses of epithelial Sertoli cells of the rat testis to toll-like receptor 2 and 4 ligands: implications for studies of testicular inflammation using bacterial lipopolysaccharides. Innate Immun. 2011;17:123-36.

8. Palladino M, Johnson T, Gupta R, Chapman J, Ojha P. Members of the tolllike receptor family of innate immunity pattern-recognition receptors are abundant in the male rat reproductive tract. Biol Reprod. 2007;76:958-64.

9. Girling JE, Hedger MP. Toll-like receptors in the gonads and reproductive tract: emerging roles in reproductive physiology and pathology. Immunol Cell Biol. 2007:85:481-9.

10. Biswas B, Yenugu S. Antimicrobial responses in the male reproductive tract of lipopolysaccharide challenged rats. Am J Reprod Immunol. 2011;65:557-68.

11. Palladino MA, Mallonga TA, Mishra MS. Messenger RNA (mRNA) expression for the antimicrobial peptides beta-defensin-1 and beta-defensin-2 in the male rat reproductive tract: beta-defensin-1 mRNA in initial segment and caput epididymidis is regulated by androgens and not bacterial lipopolysaccharides. Biol Reprod. 2003;68:509-15.

12. Biswas B, Narmadha G, Choudhary M, French FS, Hall SH, Yenugu S. Identification of toll-like receptors in the rat (Rattus norvegicus): messenger RNA expression in the male reproductive tract under conditions of androgen variation. Am J Reprod Immunol. 2009;62:243-52.

13. Com E, Bourgeon F, Evrard B, Ganz T, Colleu D, Jégou B, et al. Expression of antimicrobial defensins in the male reproductive tract of rats, mice, and humans. Biol Reprod. 2003;68:95-104.
14. Wang Z, Widgren EE, Sivashanmugam P, O'Rand MG, Richardson RT Association of eppin with semenogelin on human spermatozoa. Biol Reprod. 2005;72:1064-70.

15. Yenugu S, Chintalgattu V, Wingard CJ, Radhakrishnan Y, French FS, Hall SH. Identification, cloning and functional characterization of novel betadefensins in the rat (Rattus norvegicus). Reprod Biol Endocrinol. 2006;4:7.

16. Rodrigues A, Queiróz DB, Honda L, Silva EJ, Hall SH, Avellar MC. Activation of toll-like receptor 4 (TLR4) by in vivo and in vitro exposure of rat epididymis to lipopolysaccharide from Escherichia Coli. Biol Reprod. 2008;79: 1135-47.

17. Hall SH, Hamil KG, French FS. Host defense proteins of the male reproductive tract. J Androl. 2002;23:585-97.

18. O'Bryan MK, Schlatt S, Phillips DJ, De Kretser DM, Hedger MP. Bacterial lipopolysaccharide-induced inflammation compromises testicular function at multiple levels in vivo. Endocrinology. 2000;141:238-46.

19. Allen J, Diemer T, Janus P, Hales K, Hales B. Bacterial endotoxin lipopolysaccharide and reactive oxygen species inhibit leydig cell steroidogenesis via perturbation of mitochondria. Endocrine. 2004;25:265-75.

20. Li Z, Zhang D, He Y, Ding Z, Mao F, Luo T, et al. Lipopolysaccharide compromises human sperm function by reducing intracellular cAMP. Tohoku J Exp Med. 2016;238:105-12.

21. Biswas B, Yenugu S. Lipopolysaccharide induces epididymal and testicular antimicrobial gene expression in vitro: insights into the epigenetic regulation of sperm-associated antigen 11e gene. Immunogenetics. 2013;65: 239-53.

22. Bartels K, Grenz A, Eltzschig HK. Hypoxia and inflammation are two sides of the same coin. Proc Natl Acad Sci U S A. 2013;110:18351-2.

23. Devraj G, Beerlage C, Brüne B, VAJ K. Hypoxia and HIF-1 activation in bacterial infections. Microbes Infect. 2017;19:144-56.

24. Semenza GL. Hypoxia-inducible factors in physiology and medicine. Cell. 2012;148:399-408

25. Yee Koh M, Spivak-Kroizman TR, Powis G. HIF-1 regulation: not so easy come, easy go. Trends Biochem Sci. 2008;33:526-34.

26. Brocato J, Chervona Y, Costa M. Molecular responses to hypoxia-inducible factor $1 \mathrm{a}$ and beyond. Mol Pharmacol. 2014;85:651-7.

27. Dehne N, Brüne B. HIF-1 in the inflammatory microenvironment. Exp Cell Res. 2009;315:1791-7.

28. Tewari R, Choudhury SR, Ghosh S, Mehta VS, Sen E. Involvement of TNFainduced TLR4-NF-KB and TLR4-HIF-1a feed-forward loops in the regulation of inflammatory responses in glioma. J Mol Med. 2012;90:67-80.

29. Imtiyaz HZ, Simon MC. Hypoxia-inducible factors as essential regulators of inflammation. Curr Top Microbiol Immunol. 2010;345:105-20.

30. Powell JD, Elshtein R, Forest DJ, Palladino MA. Stimulation of hypoxiainducible Factor-1 alpha (HIF-1a) protein in the adult rat testis following ischemic injury occurs without an increase in HIF-1a messenger RNA expression. Biol Reprod. 2002;67:995-1002.

31. Palladino MA, Shah A, Tyson R, Horvath J, Dugan C, Karpodinis M. Myeloid cell leukemia-1 (Mc1-1) is a candidate target gene of hypoxia-inducible factor-1 (HIF-1) in the testis. Reprod Biol Endocrinol. 2012;10:104.

32. Frede S, Berchner-Pfannschmidt U, Fandrey J. Regulation of hypoxiainducible factors during inflammation. Meth Enzymol. 2007:435:405-19.

33. Frede S, Stockmann C, Freitag P, Fandrey J. Bacterial lipopolysaccharide induces HIF-1 activation in human monocytes via p44/42 MAPK and NFkappaB. Biochem J. 2006;396:517-27.

34. Gorlach A, Bonello S. The cross-talk between NF-KB and HIF-1: further evidence for a significant liaison. J Biochem. 2008;412:e17.

35. Palladino MA, Pirlamarla PR, McNamara J, Sottas CM, Korah N, Hardy MP, et al. Normoxic expression of hypoxia-inducible factor 1 in rat Leydig cells in vivo and in vitro. J Androl. 2011;32:307-23.

36. Bonello S, Zähringer C, BelAiba RS, Djordjevic T, Hess J, Michiels C, et al. Reactive oxygen species activate the HIF-1alpha promoter via a functional NFkappaB site. Arterioscler Thromb Vasc Biol. 2007;27:755-61.

37. Rius J, Guma M, Schachtrup C, Akassoglou K, Zinkernagel AS, Nizet V, et al. $\mathrm{NF}-|[\mathrm{kgr}]| B$ links innate immunity to the hypoxic response through transcriptional regulation of HIF-1|[agr]|. Nature. 2008;453:807-11.

38. Blouin CC, Pagé EL, Soucy GM, Richard DE. Hypoxic gene activation by lipopolysaccharide in macrophages: implication of hypoxia-inducible factor 1a. Blood. 2004;103:1124-30.

39. Hedger MP. Toll-like receptors and signalling in spermatogenesis and testicular responses to inflammation—a perspective. J Reprod Immunol. 2011:88:130-41. 
40. Zhou Z, Zhu X, Chen J, Yang S, Sun R, Yang G. The interaction between tolllike receptor 4 signaling pathway and hypoxia-inducible factor 1a in lung ischemia-reperfusion injury. J Surg Res. 2014;188:290-7.

41. Parker MI, Palladino MA. MicroRNAs downregulated following immune activation of rat testis. Am J Repro Immunol. 2017;00:e12673.

42. Bhushan S, Tchatalbachev S, Lu Y, Fröhlich S, Fijak M, Vijayan V, et al. Differential activation of inflammatory pathways in testicular macrophages provides a rationale for their subdued inflammatory capacity. J Immunol. 2015;194:5455-64.

43. Hales DB. Testicular macrophage modulation of Leydig cell steroidogenesis. J Reprod Immunol. 2002;57:3-18.

44. Bourdon V, Defamie N, Fenichel P, Pointis G. Regulation of tissue-type plasminogen activator and its inhibitor (PAl-1) by lipopolysaccharideinduced phagocytosis in a Sertoli cell line. Exp Cell Res. 1999;247:367-72.

Ready to submit your research? Choose BMC and benefit from:

- fast, convenient online submission

- thorough peer review by experienced researchers in your field

- rapid publication on acceptance

- support for research data, including large and complex data types

- gold Open Access which fosters wider collaboration and increased citations

- maximum visibility for your research: over $100 \mathrm{M}$ website views per year

At BMC, research is always in progress.

Learn more biomedcentral.com/submissions 